\title{
Behavioral Changes in Mice Lacking Interleukin-33
}

\author{
${ }^{-}$Eisuke Dohi, Eric Y. Choi, Indigo V.L. Rose, Akiho S. Murata, Sharon Chow, ${ }^{\circ}$ Minae Niwa, and \\ (1) Shin-ichi Kano
}

DOI:http://dx.doi.org/10.1523/ENEURO.0147-17.2017

Department of Psychiatry and Behavioral Sciences, The Johns Hopkins University School of Medicine, Baltimore, MD 21287

\section{Visual Abstract}

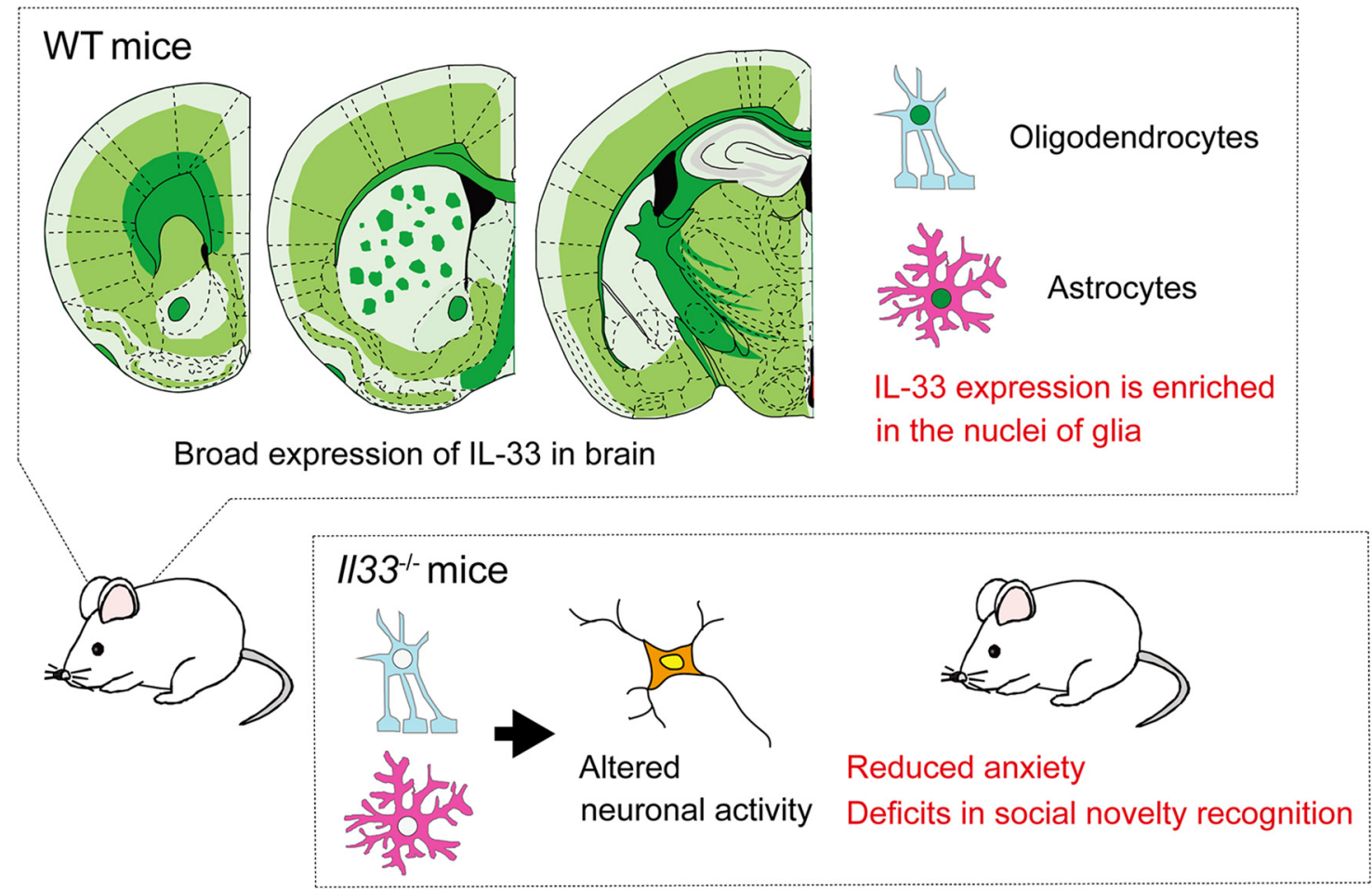

\section{Significance Statement}

Interleukin (IL)-33 is expressed in the developing and mature brain; however, its role in brain function and

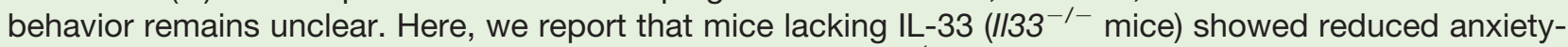
like behaviors and impaired social novelty recognition. In $/ / 33^{-1-}$ mice, c-Fos immunoreactivity was altered in several brain areas, including those related to anxiety, after a stressful behavioral assay. Notably, IL-33 expression was not correlated with c-Fos immunoreactivity, and no IL-33 expression changes were seen after the behavioral assay. Thus, our study suggests that //33 deficiency impairs multiple behaviors, such as anxiety and social behaviors, by altering brain development/maturation. These findings will advance our understanding of the physiological role of immune molecules in brain function and behavior. 


\section{Abstract}

Interleukin (IL)-33 is a member of the IL-1 family of cytokines. IL-33 is expressed in nuclei and secreted as alarmin upon cellular damage to deliver a danger signal to the surrounding cells. Previous studies showed that IL-33 is expressed in the brain and that it is involved in neuroinflammatory and neurodegenerative processes in both humans and rodents. Nevertheless, the role of IL-33 in physiological brain function and behavior remains unclear.

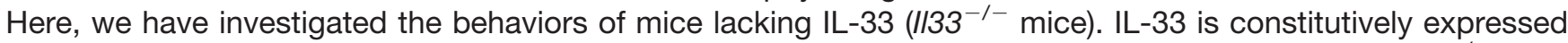
throughout the adult mouse brain, mainly in oligodendrocyte-lineage cells and astrocytes. Notably, $I / 33^{-1-}$ mice exhibited reduced anxiety-like behaviors in the elevated plus maze (EPM) and the open field test (OFT), as well as deficits in social novelty recognition, despite their intact sociability, in the three-chamber social interaction test. The immunoreactivity of c-Fos proteins, an indicator of neuronal activity, was altered in several brain regions implicated in anxiety-related behaviors, such as the medial prefrontal cortex (MPFC), amygdala, and piriform cortex (PCX), in $/ 133^{-/-}$mice after the EPM. Altered c-Fos immunoreactivity in $1 / 33^{-1-}$ mice was not correlated with IL-33 expression in wild-type (WT) mice nor was IL-33 expression affected by the EPM in WT mice. Thus, our study has revealed that $I / 33^{-1-}$ mice exhibit multiple behavioral deficits, such as reduced anxiety and impaired social recognition. Our findings also indicate that IL-33 may regulate the development and/or maturation of neuronal circuits, rather than control neuronal activities in adult brains.

Key words: anxiety; astrocytes; cytokines; IL-33; oligodendrocytes; social behavior

\section{Introduction}

Interleukin (IL)-33 is a member of the IL-1 family of cytokines, which contains 11 members, including IL-1 $\alpha$, IL-1 $\beta$, and IL-18 (Molofsky et al., 2015; Liew et al., 2016). IL-33 is expressed in the nuclei of various types of cells and is also secreted as a cytokine, particularly by barrier cells such as endothelial and epithelial cells, as a signal of cellular injury and necrosis (Molofsky et al., 2015; Liew et al., 2016; Martin and Martin, 2016). Thus, IL-33 is categorized as a nuclear alarmin, an endogenous molecule that is released on tissue injury to promote innate immune responses, similar to high-mobility group box 1 protein (HMGB1) and IL-1 $\alpha$. Upon secretion, IL-33 binds to the IL-33 receptor ST2 on its target cells and recruits IL-1 receptor accessory proteins (IL1RAcPs) to form a heterotrimeric signaling complex. This complex activates $\mathrm{NF}-\kappa \mathrm{B}, \mathrm{ERK} 1 / 2$, JNK, and p38 MAPK signaling to induce the expression of downstream genes (Molofsky et al., 2015; Liew et al., 2016; Martin and Martin, 2016). IL-33 can also function as a transcriptional modulator (Molofsky et al., 2015; Liew et al., 2016; Martin and Martin, 2016).

Received April 27, 2017; accepted December 3, 2017; First published December 11, 2017.

The authors declare no competing financial interests.

Author contributions: E.D., M.N., and S.-i.K. designed research; E.D., E.Y.C., I.V.L.R., A.S.M., and S.C. performed research; E.D., E.C., I.V.L.R., A.S.M., S.C., and S.-i.K. analyzed the data; E.D. and S.-i.K. wrote the paper.

This work was supported by the National Institute of Mental Health Grant R0O MH093458 and by the Johns Hopkins Medicine Discovery Fund. The Zeiss LSM 700 confocal microscope used in this study was funded by National Institute of Health Grant S10OD016374.

Acknowledgment: We thank Dr. Mikhail V. Pletnikov, Josh Crawford, Brian D. Lo, and Timar A. Mascio for technical advice and help.

Correspondence should be addressed to Shin-ichi Kano, Department of Psychiatry and Behavioral Sciences, The Johns Hopkins University School of Medicine, 600 North Wolfe Street, Meyer 3-143, Baltimore, MD 21287, E-mail: skano2@jhmi.edu.

DOI:http://dx.doi.org/10.1523/ENEURO.0147-17.2017

Copyright (C) 2017 Dohi et al.

This is an open-access article distributed under the terms of the Creative Commons Attribution 4.0 International license, which permits unrestricted use, distribution and reproduction in any medium provided that the original work is properly attributed.
IL-33 contains a nuclear localization sequence and a DNA-binding domain at the $\mathrm{N}$-terminus and binds to the nucleosome acidic pocket formed by the histone H2AH2B dimer (Roussel et al., 2008). IL-33 also binds to the histone methyltransferase SUV39H1 and NF- $\kappa \mathrm{B}$, modulating their activity (Ali et al., 2011). Nevertheless, the precise mechanisms by which IL-33 regulates gene expression in various cell types remain to be elucidated.

IL-33 is expressed in the central nervous system (Schmitz et al., 2005; Wicher et al., 2013; Gadani et al., 2015). The original report on the discovery of IL-33 showed that mRNA expression was most abundant in the brain and spinal cord (Schmitz et al., 2005). Subsequent studies added that the pattern of IL-33 expression changes in a temporal and spatial manner during brain development, with its expression enriched in astrocytes in the mature brain (Wicher et al., 2013). Furthermore, a recent report revealed that IL-33 is predominantly expressed in postmitotic oligodendrocytes in the white matter (Gadani et al., 2015). Roles of IL-33 in neuroinflammation and neurodegeneration have been reported as well (Chapuis et al., 2009; Jiang et al., 2012; Yu et al., 2012; Xiong et al., 2014; Gadani et al., 2015; Fu et al., 2016). Human genetic studies reported that a singlenucleotide polymorphism (SNP) in IL-33 is associated with increased risk for the late-onset form of Alzheimer's disease (Chapuis et al., 2009; Yu et al., 2012). Expression levels of IL-33 and its receptor ST2 are strongly increased around the amyloid plaques in the brains of patients with Alzheimer's disease (Xiong et al., 2014). Furthermore, rodent studies showed that IL-33 had a therapeutic effect in a mouse model of Alzheimer disease, attenuating cellular pathologies and recovering behavioral phenotypes (Fu et al., 2016). Anti-inflammatory and potential therapeutic roles of IL-33 were also suggested by findings from mouse models of spinal cord injury and experimental autoimmune encephalitis (Jiang et al., 2012; Gadani et al., 2015). Taken together, these findings highlight the significant role of glial IL-33 in neurodegeneration, injury, and inflammation in the brain. Nevertheless, the physiological 
role of IL-33 in brain function and behavior remains poorly understood.

In this study, we provide evidence that IL-33 is involved in anxiety-related and social behaviors. In the elevated plus maze (EPM) and the open field test (OFT), mice

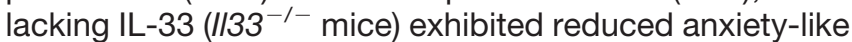
behaviors compared to wild-type (WT) mice. In the threechamber social interaction test, $/ 133^{-/-}$mice showed deficits in social novelty recognition, despite their intact sociability. In the adult mouse brain, IL-33 expression was detected in the cellular nuclei of various brain regions including the cortex, corpus callosum (CC), hypothalamus, amygdala, and hippocampus. The expression of IL-33 in these brain regions was localized primarily to Olig2-expressing oligodendrocyte-lineage cells and, to a lesser extent, $\mathrm{S} 100 \beta$-expressing astrocytes. Assessment of neuronal activity by analyzing c-Fos expression in neurons immediately after the EPM suggested altered neuronal activities in multiple brain regions, including those related to anxiety in $1133^{-1-}$ mice. Nonetheless, altered c-Fos immunoreactivity in $/ / 33^{-1-}$ mice was not correlated with IL-33 expression in WT mice nor was IL-33 expression affected by the EPM in WT mice. Thus, our study suggested that I/33 deficiency results in multiple behavioral deficits, such as reduced anxiety and impaired social novelty recognition, possibly via dysregulated developmental and/or maturation of multiple neuronal circuits.

\section{Materials and Methods}

\section{Animals}

$1 / 33^{-1-}$ mice on a C57BL/6J background were provided by Amgen Inc. C57BL/6J mice were purchased from The Jackson Laboratory. Mice were housed in a specific pathogen-free animal facility under controlled temperatures $\left(23 \pm 3^{\circ} \mathrm{C}\right)$ and controlled light schedule (lights on from 7 A.M. to 9 P.M.), with food and water available. Unless stated otherwise, male mice were used for the experiments at 8-10 weeks of age. All experimental procedures were performed in accordance with the National Institutes of Health Guidelines for the Care and Use of Laboratory Animals, under the animal protocols approved by the Institutional Animal Care and Use Committee.

\section{Behavioral assays}

Behavioral assays were performed on male mice at 8-10 weeks of age, following the established protocols. All the assays were conducted between 10 A.M. and 3 P.M. during the light phase. Two independent cohorts of mice were used in the present study. In the first cohort, mice were tested in the OFT and then in the elevated-plus maze on the following day. In the second cohort, mice were assessed in the three-chamber social interaction test.

\section{OFT}

Novelty-induced activity in the open field was assessed as described previously (Niwa et al., 2010; Zhang et al., 2011; Dubal et al., 2015; Ertürk et al., 2016; Xiong et al., 2017). Locomotion, rearing, and center time were measured for 10 min using a Photobeam Activity System (PAS-Open Field, San Diego Instruments). The PAS system consisted of two vertically stacked frames, each containing infrared lasers arranged in a $16 \times 16$ grid, which detected mouse movement, including ambulation and rearing. The open field box and surrounding photobeam apparatus were housed in a ventilated cabinet. Single-beam breaks were automatically recorded as "counts" and the PAS system automatically started recording counts once the mouse started moving. The total counts were recorded and the percentages of center counts (defined as those in the central $27.5 \times 27.5 \mathrm{~cm}$ area) to total counts were calculated.

\section{EPM}

General anxiety was evaluated by the EPM as described previously (Walf and Frye, 2007; Sidor et al., 2010; Montalvo-Ortiz et al., 2016). The maze consisted of two closed arms, with walls of height $20 \mathrm{~cm}$, and two open arms extending from a central platform, raised to a height of $40 \mathrm{~cm}$ above the floor. Mice were placed in the central platform of the maze facing an open arm and allowed to explore the maze for $5 \mathrm{~min}$. The EPM was conducted in the light condition (at 150 lux) so mice could perceive the difference between open and closed arms. Mouse activity was recorded on videotape and the following measurements were manually quantified: total number of entries into the arms, number of entries into closed/open arms (defined as all four limbs entering the arm), and total time spent in closed/open arms.

\section{Three-chamber social interaction test}

The three-chamber social interaction test was conducted as previously described (Moy et al., 2004; Gkogkas et al., 2013; Lipina et al., 2013; Filiano et al., 2016). All mice were tested in a nonautomated three-chambered box. Dividing walls had retractable doorways allowing access into each chamber. Mice were acclimated to the three-chambered box for $4 \mathrm{~d}$ before the test $(10 \mathrm{~min} / \mathrm{d})$. On the test day, mice were transported to the testing room and habituated for at least $1 \mathrm{~h}$ before the experiment. A white noise generator was used to mitigate any unforeseen noises. The subject mouse was habituated in the chamber with two empty cylinders for $10 \mathrm{~min}$. Then, the "toy" object was placed in one of the cylinders and mouse (stranger 1 ) was placed in another cylinder for the "sociability" trial. Mice were allowed to explore the chambers for $10 \mathrm{~min}$. In the next "social novelty preference" trial, stranger 1 was kept in the cylinder as the familiar mouse and the toy object was replaced with a novel mouse (stranger 2). The subject mouse was again allowed to explore the chambers. During these two trials, mouse activities were recorded on video and the time spent sniffing each cylinder was manually measured. Preference index was calculated as follows. For sociability test: (sniffing time to mouse) $\times 100 /$ (sniffing time to mouse + sniffing time to object) -50 . For social novelty preference test: (sniffing time to novel mouse) $\times 100 /$ (sniffing time to novel mouse + sniffing time to familiar mouse) -50 .

\section{Assessment of inter-rater reliability}

In the EPM and three-chamber social interaction test, two examiners blinded to genotype followed a rigorous protocol with which highly reproducible results were obtained previously in our group. Inter-rater reliability was 
Table 1. ICC

\begin{tabular}{|c|c|c|c|c|}
\hline Figure & Data structure & Type of test & Sample size & Statistical data \\
\hline Fig. $2 A-C$ & Normal distribution & $\begin{array}{l}\text { Intraclass correlation } \\
\text { coefficient }\end{array}$ & $n=15$ (elevated-plus maze test) & $\begin{array}{l}\text { Time spent in open arm; ICC }=0.98(95 \% \mathrm{Cl} 0.94-0.993) \\
\text { Open arm entries; ICC }=0.97(95 \% \mathrm{Cl} 0.898-0.99) \\
\text { Total entries; ICC }=0.94(95 \% \mathrm{Cl} 0.818-0.98)\end{array}$ \\
\hline Fig. $5 \mathrm{~A}, \mathrm{C}$ & Normal distribution & $\begin{array}{l}\text { Intraclass correlation } \\
\text { coefficient }\end{array}$ & $\begin{array}{l}\text { Sniffing time (three-chamber ocial interaction test); } n=64 \\
\text { (from } 16 \text { mice) }\end{array}$ & Sniffing time; ICC $=0.983(95 \% \mathrm{Cl} 0.971-0.989)$ \\
\hline Fig. 5B,D & Normal distribution & $\begin{array}{l}\text { Intraclass correlation } \\
\text { coefficient }\end{array}$ & $\begin{array}{l}\text { Preference index (three-chamber social interaction test); } \\
n=16\end{array}$ & $\begin{array}{l}\text { Preference index (sociability); ICC }=0.987(95 \% \mathrm{Cl} 0.939-0.992) \\
\text { Preference index (social novelty preference); ICC }=0.939 \\
(95 \% \mathrm{Cl} 0.806-0.98)\end{array}$ \\
\hline
\end{tabular}

assessed by intraclass correlation coefficient (ICC; Shrout and Fleiss, 1979; Langford et al., 2010; Hallgren, 2012; Koo and Li, 2016). ICC estimates and their 95\% confident interval were calculated using SPSS statistical package version 25 (SPSS Inc) with the following parameters: meanrating $(k=2)$, absolute-agreement, two-way random effects model. All data displayed high inter-rater reliability, with ICC rating ranged from 0.939 to 0.984 (Table 1).

\section{Immunohistochemistry}

Mice were anesthetized and transcardially perfused, first with ice-cold PBS and then with $4 \%$ paraformaldehyde (PFA) in PBS. The brains were removed and postfixed in the same fixative for $24 \mathrm{~h}$, then incubated in $10 \%$ and $30 \%(\mathrm{w} / \mathrm{v})$ sucrose in PBS. Free-floating coronal sections $(40-\mu \mathrm{m}$ thick) were prepared with a Cryostat (CM 3050S, Leica). For immunohistochemistry, the following primary antibodies were used: goat anti-mouse IL-33 (R\&D Systems, RRID: AB_884269) at 1:200 dilution, mouse anti-NeuN (Merck Millipore, RRID: AB_2298772) at 1:500 dilution, rabbit anti-lba1 (Wako Chemicals, RRID: AB 839504) at 1:400 dilution, rabbit anti-S100 $\beta$ (Abcam, RRID: AB_882426) at 1:400 dilution, goat anti-c-Fos (Santa Cruz Biotechnology, RRID: AB_2106783) at 1:500 dilution, and rabbit anti-c-Fos (Cell Signaling, RRID: AB_22472111) at 1:200 dilution. Fluorescently labeled secondary antibodies Alexa Fluor 488, 546, 633 at 1:400 dilution (Thermo Fisher Scientific) and DAPI (at 1:50,000 dilution, Roche) were used for signal detection. Images were acquired using Zeiss LSM510 and LSM700 confocal microscopes with Zen software (Carl Zeiss). Images were taken at $20 \times$ and $40 \times$ magnification. Areas used for quantification were indicated with red boxes. For c-Fos quantification, maximum projection images of serial z-stack sections (21 sections at $0.75 \mu \mathrm{m})$ were constructed using Zen software.

\section{Image analysis}

Image analysis was performed as previously described (Gompf et al., 2010; Dohi et al., 2012; Gadani et al., 2015). Three to five brain sections from each animal were chosen based on anatomic landmarks to ensure that equivalent regions were analyzed. The number of IL-33-expressing cells per each visual field was quantified and compared across different brain regions. The color code of light, medium, and dark green correspond to $0-25,26-100$, and $101+$ cells/visual field, respectively. To determine the difference in IL-33 expression level between Olig2 $^{+}$and $\mathrm{S} 100 \beta^{+}$cells, the IL-33 ${ }^{+}$nuclear intensity was quantified. First, the boundary of the nucleus was traced and then superimposed onto the $\mathrm{IL}-33^{+}$image using Fiji software (Schindelin et al., 2012). Then, IL- $33^{+}$signal intensity per pixel was averaged across the nuclear area. This process was used to compare Olig2 ${ }^{+}$cells and $S 100 \beta^{+}$cells in the M2. Additionally, the percentages of $\mathrm{S} 100 \beta^{+}$, Olig2 ${ }^{+}$, and other cells among IL-33-expressing cells were quantified across brain regions. The percentages of c-Fosexpressing cells among $\mathrm{NeuN}^{+}$neurons were also quantified. The correlation between the number of IL- $33^{+}$cells and the fold change of $\mathrm{c}^{-F_{0 s}}{ }^{+}$neurons in WT mice normalized with $/ / 33^{-1-}$ mice was analyzed in the brain areas where a significant increase in c-Fos expression was observed in $1 / 33^{-1-}$ mice immediately after EPM. c-Fos fold change in WT mice was calculated as follows: \% $\mathrm{C}^{-\mathrm{Fos}^{+}}{ }^{+}$neurons $\left(\mathrm{NeuN}^{+}\right.$cells) in WT mice after EPM/the average \% c-Fos ${ }^{+}$neurons in $/ 133^{-1-}$ mice after EPM. The correlation between the \% c-Fos ${ }^{+}$neurons and the number of IL-33 ${ }^{+}$cells in WT mice was analyzed immediately after EPM. Additionally, the number of IL-33-expressing cells was analyzed in WT mice with and without the EPM. These analyses were performed blind to mouse genotype.

\section{ELISA}

Murine IL-33 concentration in serum was determined using DuoSet ELISA kits (R\&D Systems, catalog \#DY3626-05) following the manufacturer's standard protocol.

\section{Quantitative reverse transcription (qRT)-PCR analysis}

qRT-PCR was performed following a standard protocol. Total RNA was isolated using RNeasy Plus Micro kit (Qiagen), and cDNA was synthesized from using Superscript III kit (Invitrogen) with oligo(dT) 20 primers. qPCR was conducted with Maxima SYBR Green/ROX Master Mix (Thermo Fisher Scientific) on ABI 7900HT system (Applied Biosystems). Gene-specific primer sets were obtained from PrimerBank (https://pga.mgh.harvard.edu/ primerbank; Spandidos et al., 2010) or designed by using Primer-BLAST (https://www.ncbi.nlm.nih.gov/tools/primerblast/2. The primer sequences are as follows: mouse IL-33, 5'-TCCAACTCCAAGATTTCCCCG-3' and 5'-CATGCAG TAGACATGGCAGAA-3'; mouse $\beta$-actin, 5'-CCTGTATGCC TCTGGTCGTA-3' and 5'-CCATCTCCTGCTCGAAGTCT-3'.

\section{Western blotting}

Frontal cortex tissues were sectioned and lysed in RIPA buffer containing $0.1 \%$ SDS, a protease inhibitor cocktail (Roche), and a phosphatase inhibitor (Sigma Aldrich). Tissue samples were prepared on NuPAGE Bis-Tris Mini Gel (Life Technologies), followed by the transfer to PVDF membrane (Millipore) following a standard protocol. After 
Table 2. Statistical table

\begin{tabular}{llll}
\hline Figure & Data structure & Type of test & Sample size \\
Fig. 1F & Normal distribution & $\begin{array}{l}\text { Unpaired } t \text { test } \\
\text { (two-tailed) }\end{array}$ & $\begin{array}{l}\text { Olig2 }{ }^{+}: n=5 \\
\text { S } 100 \beta^{+}: n=5\end{array}$ \\
Fig. 1H & Normal distribution & One-way ANOVA & WT mice: $n=2$ (three to five images/mouse)
\end{tabular}

Statistical data

$t=3.932, \mathrm{df}=8, p=0.0043$

Cohen's $d=2.487$

$\mathrm{F}=3.328, p=0.0134, \eta^{2}=0.299$

Tukey's multiple comparison test:

mPFC vs M2: $p=0.8229$, Cohen's $d=0.523$

mPFC vs CC: $p=0.0441$, Cohen's $d=1.79$

mPFC vs Pe: $p>0.9999$, Cohen's $d=0.115$

mPFC vs BLA: $p=0.9835$, Cohen's $d=0.355$

mPFC vs CoA: $p=0.9934$, Cohen's $d=0.236$

M2 vs CC: $p=0.4619$, Cohen's $d=1.027$

M2 vs Pe: $p=0.9441$, Cohen's $d=0.435$

M2 vs BLA: $p=0.4175$, Cohen's $d=0.962$

M2 vs CoA: $p=0.9882$, Cohen's $d=0.262$

CC vs Pe: $p=0.1238$, Cohen's $d=1.791$

CC vs BLA: $p=0.0076$, Cohen's $d=3.228$

CC vs CoA: $p=0.1843$, Cohen's $d=1.309$

Pe vs BLA: $p=0.954$, Cohen's $d=0.52$

Pe vs CoA: $p=0.9997$, Cohen's $d=0.602$

BLA vs CoA: $p=0.8305$, Cohen's $d=0.139$

$H=19.22, p=0.0007, \varepsilon 2=0.534$

Dunnett's multiple comparison test:

mPFC vs M2: $p>0.9999$, Cohen's $d=0.353$

mPFC vs Pe: $p=0.4307$, Cohen's $d=1.229$

mPFC vs BLA: $p=0.0462$, Cohen's $d=1.81$

mPFC vs CoA: $p=0.1536$, Cohen's $d=1.354$

M2 vs Pe: $p=0.0929$, Cohen's $d=2.09$

M2 vs BLA: $p=0.0055$, Cohen's $d=3.246$

M2 vs CoA: $p=0.0247$, Cohen's $d=2.026$

Pe vs BLA: $p>0.9999$, Cohen's $d=0.489$

Pe vs CoA: $p>0.9999$, Cohen's $d=0.272$

BLA vs CoA: $p>0.9999$, Cohen's $d=0.127$

$t=6.911, \mathrm{df}=23, p<0.0001$

Cohen's $d=2.794$

$t=6.923, \mathrm{df}=23, p<0.0001$

Cohen's $d=2.701$

$t=0.1446, \mathrm{df}=23, p=0.8863$

Cohen's $d=0.058$

$t=4.447, \mathrm{df}=14, p=0.0006$

Cohen's $d=2.280$

mPFC; $t=2.972, \mathrm{df}=6, p=0.0249$, Cohen's $d=2.103$

$\mathrm{PCX} ; t=3.401, \mathrm{df}=6, p=0.0145$, Cohen's $d=2.406$

M2; $t=2.462, \mathrm{df}=6, p=0.0490$, Cohen's $d=1.741$

S1BF; $t=8.439, \mathrm{df}=6, p=0.0002$, Cohen's $d=5.697$

BLA; $t=1.885, \mathrm{df}=6, p=0.2047$, Cohen's $d=1.334$

CeA; $t=3.149, \mathrm{df}=5, p=0.0254$, Cohen's $d=2.177$

vHip; $t=1.414, \mathrm{df}=5, p=0.2107$, Cohen's $d=3.071$

$r=0.1295(95 \% \mathrm{Cl}-0.28$ to 0.4991$)$

$\mathrm{R}^{2}=0.01677$

$1133^{-1-}$ mice $n=5$

IL-33 in WT mouse fold change of c-Fos in WT mice normalized

with $/ 133^{-1-}$ mice

WT mice: $n=5$

$r=-0.07765(95 \% \mathrm{Cl}-0.4587$ to 0.3275$)$

$\mathrm{R}^{2}=0.006029$

$p=0.7122$

$t=0.03388, \mathrm{df}=14, p=0.9735$

Cohen's $d=0.017$

$t=0.2921, \mathrm{df}=5, p=0.7820$

Cohen's $d=0.221$

$t=0.3453, \mathrm{df}=6, p=0.7416$

Cohen's $d=0.224$

Genotype: $F_{(1,22)}=0.09669, p=0.7588, \eta^{2}=0.009$

Mouse/Object: $F_{(1,22)}=54.44, p<0,0001$

Interaction: $F_{(1,2)}=0.9178, p=0.3485$

Sidak's multiple comparisons test:

Mouse/Object, WT: $p<0.0001$

Mouse/Object, $/ 133^{-1-}: p<0.0001$

$t=0.9374, \mathrm{df}=22, p=0.3587$

Cohen's $d=0.395$ 
Table 2. Continued

\begin{tabular}{|c|c|c|c|c|}
\hline Figure & Data structure & Type of test & Sample size & Statistical data \\
\hline Fig. $5 \mathrm{C}$ & $\begin{array}{l}\text { Two-factors } \\
\text { (genotype and } \\
\text { chamber) }\end{array}$ & $\begin{array}{l}\text { Two-way ANOVA } \\
\text { with RM }\end{array}$ & $\begin{array}{l}\text { WT mice: } n=15 \\
I / 33^{-/-} \text {mice: } n=9\end{array}$ & $\begin{array}{l}\text { Genotype: } F_{(1,22)}=0.0224, p=0.8824, \eta^{2}=0.043 \\
\text { Familiar/Novel: } F_{(1,22)}=26.34, p<0,0001 \\
\text { Interaction: } F_{(1,22)}=4.681, p=0.0416 \\
\text { Sidak's multiple comparisons test: } \\
\text { Familiar/Novel, WT: } p<0.0001 \\
\text { Familiar/Novel, } / / 33^{-/-}: p=0.1420\end{array}$ \\
\hline Fig. 5D & Normal distribution & $\begin{array}{l}\text { Unpaired } t \text { test } \\
\text { (two-tailed) }\end{array}$ & $\begin{array}{l}\text { WT mice: } n=15 \\
\| / 33^{-/-} \text {mice: } n=9\end{array}$ & $\begin{array}{l}t=2.407, \mathrm{df}=22, p=0.0249 \\
\text { Cohen's } d=1.085\end{array}$ \\
\hline
\end{tabular}

* In Fig. 1I, we did not include CC data for analysis because we could not detect IL- $33^{+} \mathrm{S} 100 \beta^{+}$astrocytes in CC. In the Kruskal-Wallis test, we calculated $\varepsilon^{2}$ for effect size: $\varepsilon^{2}=H /\left(\left(n^{2}-1\right) /(n+1)\right)$. $H$, Kruskal-Wallis test statistic value; $n$ : total number of observations (King and Minium, 2003).

blocking in 5\% skim milk/PBS/0.1\% Tween $\AA 20$ (PBS-T) for $1 \mathrm{~h}$, the membrane was incubated with the primary antibody overnight at $4^{\circ} \mathrm{C}$ and then incubated with the secondary andibody for $1 \mathrm{~h}$ at room temperature. Gel images were captured by ImageQuant LAS 4000 LAS 4000 mini (GE Healthcare) and analyzed by ImageJ (Schneider et al., 2012). The following primary antibodies were used: goat antimouse IL-33 (R\&D Systems, RRID: AB_884269), diluted 1:1000, and mouse anti- $\beta$-actin, diluted 1:5000 (Santa Cruz Biotechnology, RRID: AB_626632).

\section{Statistical analysis}

Data were analyzed using Student's $t$ test, one-way ANOVA, Kruskal-Wallis test, and two-way repeated measures ANOVA (two-way RM ANOVA) using GraphPad Prism 7 (GraphPad Software) and SigmaStat 4.0 (Systat Software). Post hoc analyses for one-way ANOVA, Kruskal-Wallis test, and two-way RM ANOVA were performed using Tukey's, Dunnett's, and Sidak's method, respectively. Significant differences were accepted at $p<$ 0.05 . All data are presented as mean \pm SEM.

\section{Results}

\section{Localization of IL-33 to the nuclei of oligodendrocyte-lineage cells and astrocytes in the adult mouse brain}

Although previous studies have shown that IL-33 is mostly expressed in the nuclei of oligodendrocytes in the adult mouse brain (Gadani et al., 2015), it is not clear whether IL-33 shows a similar expression pattern across brain regions. We assessed the expression patterns of IL-33 with immunohistochemistry in several distinct regions of the adult mouse brain (Fig. 1). First, we compared IL-33 expression patterns between $I / 33^{-1-}$ and WT mice to verify the specificity of anti-IL-33 antibody. The results showed that IL-33 immunostaining was mainly colocalized to the cell nucleus and did not show any nonspecific signals (Fig. 1A,B). IL-33 proteins were expressed constitutively in the brains of WT mice. In contrast, IL-33 proteins were not detected in the peripheral blood of WT mice under physiological conditions (Fig. 1C). We then assessed IL-33 expression and its colocalization to specific cell types in various brain regions (Fig. $1 D, E, G, H$ ). Consistent with previous studies, IL-33-expressing cells were most abundant in white matter, such as the CC (Fig. 1D). IL-33expressing cells were also distributed throughout the superficial layers of the cortex, e.g., medial prefrontal cortex (mPFC), piriform cortex (PCX), periventricular hypo- thalamic nucleus $(\mathrm{Pe})$, central amygdala $(\mathrm{CeA})$, basolateral amygdala (BLA), cortical amygdala (CoA), and hippocampus (Fig. 1D). At the cellular level, IL-33 was mainly colocalized to the nuclei of both Olig2 ${ }^{+}$oligodendrocytelineage cells and $\mathrm{S} 100 \beta^{+}$astrocytes (Fig. 1E). Higher IL-33 signals were observed in Olig2 ${ }^{+}$cells compared to $\mathrm{S} 100 \beta^{+}$astrocytes as shown in the M2 (Fig. 1F). Notably, we found that IL-33 colocalization patterns varied across brain regions (Fig. 1G). In the CC and M2, IL-33 was predominantly expressed in Olig2 ${ }^{+}$cells (Fig. 1E,G-I). In the $\mathrm{MPFC}$, IL-33 was expressed in both Olig2 ${ }^{+}$cells and S $100 \beta^{+}$astrocytes (Fig. 1E,G-I). In the Pe, BLA, and CoA, IL-33 was predominantly expressed in $\mathrm{S} 100 \beta^{+}$astrocytes (Fig. 1E,I-K). Although IL-33 signals did not generally localize to neurons $\left(\mathrm{NeuN}^{+}\right.$cells) or microglia (lba1 ${ }^{+}$cells; Fig. 1J), a small group of IL- $33^{+}$neurons were detected in the granular cell layer of ventral dentate gyrus (vDG; Fig. $1 K)$. These results suggest that IL-33 expression either represents subpopulations of Olig $2^{+}$and $\mathrm{S} 100 \beta^{+}$cells or is modified by local neuronal activity. Thus, our detailed analysis of IL-33 expression in subregions of the brain identified its complex expression pattern in the adult mouse brain, underscoring a fundamental role of IL-33 in brain function and behavior.

\section{Reduced anxiety-like behaviors in $/ 133^{-/-}$mice}

Previous studies on postmortem brains of patients with mood disorders revealed alterations in the numbers of oligodendrocytes and astrocytes, and their gene expression patterns (Hamidi et al., 2004; Uranova et al., 2004; Aston et al., 2005; Edgar and Sibille, 2012; Nagy et al., 2015). Evidence obtained in rodent studies also supports the involvement of oligodendrocytes and astrocytes in anxietyrelated behaviors. Genetic manipulation of several oligodendrocyte-related genes, such as Cnp1 and Plp1, led to altered anxiety-related behaviors (Tanaka et al., 2009; Edgar et al., 2011). Loss of astrocytes in the prefrontal cortex was also shown to induce anxiety-like behaviors in rats (Banasr and Duman, 2008). Given the enriched expression of IL-33 in oligodendrocyte-lineage cells and astrocytes, we assessed the impact on //33 deficiency on anxiety-related behaviors. As shown in Figure $2 A, B, \| / 33^{-1-}$ mice entered the open arms more frequently and spent more time in the open arms in the EPM. There was no significant difference between WT and $I / 33^{-1-}$ mice in total number of entries (Fig. $2 C)$. Consistent with these findings, $/ / 33^{-1-}$ mice spent more time in the center area of the open field compared to WT mice in a novel environment using a 10-min OFT (Fig. 2D). 

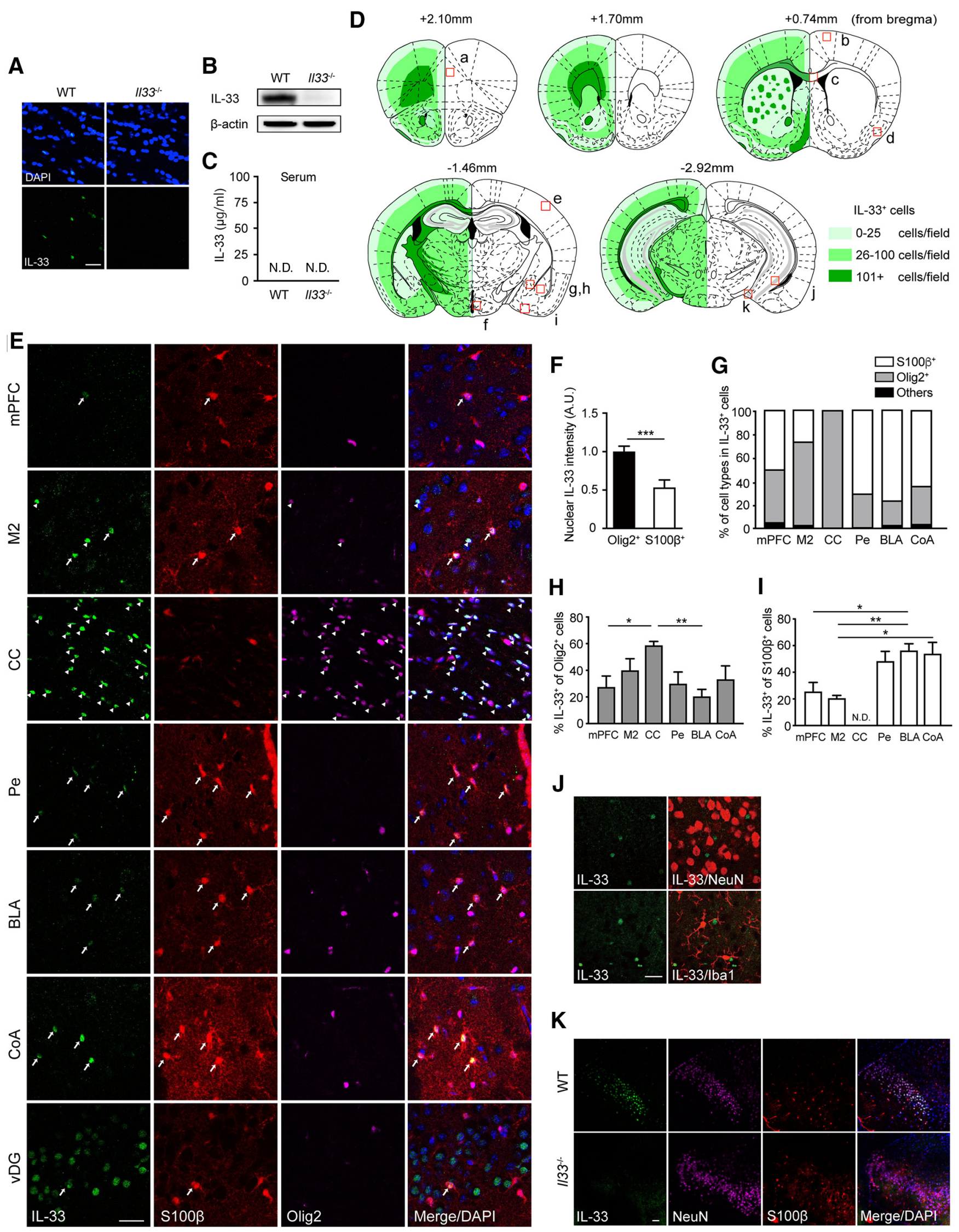

H
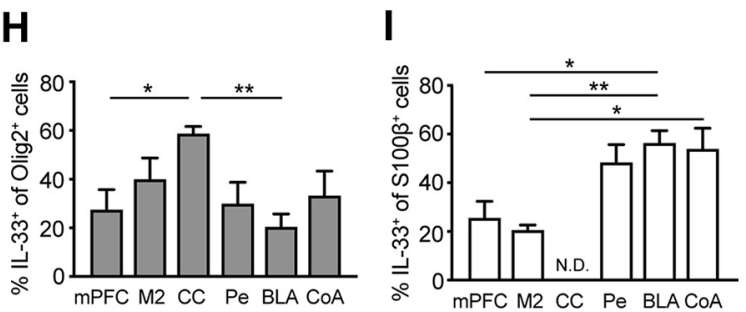

$\mathbf{J}$

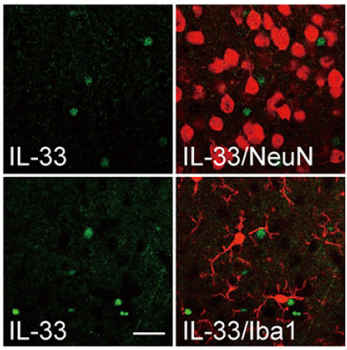

K

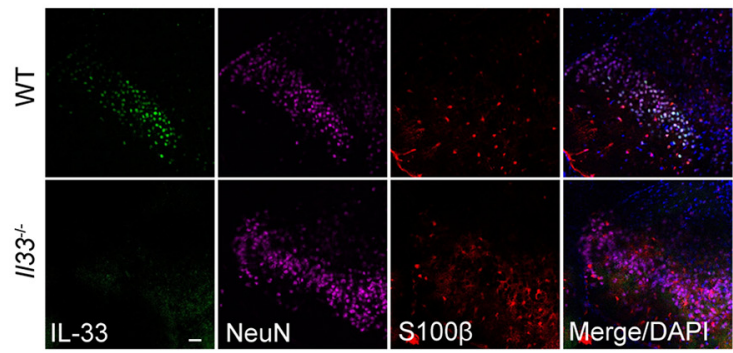

Figure 1. IL-33 expression patterns in the adult mouse brain. $\boldsymbol{A}$, Validation of specificity of IL-33 immunostaining using brain sections (CC) from WT and $/ / 33^{-/-}$mice. $\boldsymbol{B}$, Western blot analysis of IL-33 expression in the cortex from WT and $/ / 33^{-/-}$mice. $\beta$-actin was used as an 


\section{continued}

internal control for protein loading. C, Absence of IL-33 proteins in the peripheral blood of WT mice. The levels of serum IL-33 proteins were below the detection threshold of ELISA assay (15.6 pg/ml). N.D., not detected. $\boldsymbol{D}$, Schematic illustration of the distribution of IL-33expressing cells. The number of IL-33-expressing cells was quantified at $20 \times$ under a fluorescence microscope. Light, medium, and dark green correspond to $0-25,26-100$, and $101+$ cells per field, respectively. Small red boxes indicate the area analyzed in $\boldsymbol{E}-\boldsymbol{K}$ and Figs. 3 , $4 A-D$ : $\boldsymbol{a}, \mathrm{mPFC} ; \boldsymbol{b}$, secondary motor cortex (M2); $\boldsymbol{c}, \mathrm{CC} ; \boldsymbol{d}, \mathrm{PCX} ; \boldsymbol{e}$, primary S1BF; $\boldsymbol{f}$, Pe; $\boldsymbol{g}, \mathrm{CeA} ; \boldsymbol{h}, \mathrm{BLA} ; \boldsymbol{i}$, CoA; $\boldsymbol{j}$, ventral hippocampus (vHip); $\boldsymbol{k}$, vDG. $\boldsymbol{E}$, Representative pictures of IL-33 expression in several brain regions. Arrows, IL-33 $3^{+}$astrocytes (S100 $\beta^{+}$cells); arrowheads, IL-33 ${ }^{+}$oligodendrocyte-lineage cells (Olig2 ${ }^{+}$cells). $\boldsymbol{F}$, The average nuclear intensity of IL-33 between Olig2 ${ }^{+}$cells and S100 $\beta^{+}$

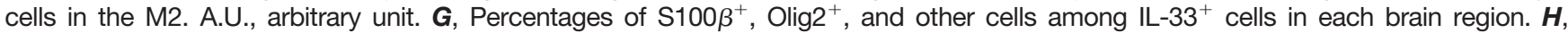
Comparison of IL-33 expression in Olig2 ${ }^{+}$cells across brain regions. I, Comparison of IL-33 expression in S100 $\beta^{+}$cells across brain regions. We also observed Olig2 ${ }^{+}$and $\mathrm{S} 100 \beta^{+}$cells, but these cells are not included in this graph. $\mathbf{J}$, No colocalization of IL-33 signals to neurons (NeuN ${ }^{+}$ cells) or microglia (lba1 ${ }^{+}$cells) in most brain regions. Representative pictures of the M2 are shown. $K$, IL-33 colocalization to neurons in the granular layer of vDG. Scale bar, $30 \mu \mathrm{m}$. Each bar represents mean \pm SEM; $* p<0.05, * * p<0.01$ (Student's $t$ test, one-way ANOVA with post hoc Tukey's test, and Kruskal-Wallis test with post hoc Dunnett's test; see Table 2 for the detail of statistical analysis).

These findings show that $1 / 33^{-/-}$mice exhibit reduced anxiety-like behaviors, suggesting that the absence of IL-33 may influence neuronal function relevant for anxiety-related behavior.

\section{Increased neuronal c-Fos immunoreactivity in brain regions linked to anxiety-related behavior in $1 / 33^{-/-}$ mice}

To understand the impact of //33 deficiency on neuronal activity, we determined whether c-Fos immunoreactivity, an indicator of neuronal activity, was altered in brain regions implicated in anxiety-related behaviors (Silveira et al., 1993; Duncan et al., 1996; Linden et al., 2003; Linden et al., 2004). The number of c-Fos-expressing neurons (c-Fos ${ }^{+} \mathrm{NeuN}^{+}$ cells) was altered in $/ 133^{-1-}$ mice compared to WT mice in various brain regions after the EPM (Fig. 3). The prominent increase in c-Fos expression was observed in the M2, CoA, anterior olfactory area, and somatosensory cortex in $1133^{-1-}$ mice (Fig. $3 A, B$; data not shown). As for the areas associated with anxiety-related behavior, increased neuronal c-Fos expression was observed in the MPFC and CoA while decreased neuronal c-Fos expression was detected in the $\mathrm{CeA}$ (Fig. $3 A, B$ ). These findings demonstrated that //33 deficiency led to altered neuronal activity in various brain regions, including those related to anxiety.

\section{Relationship between IL-33 expression and neuronal activity}

We next determined whether IL-33 expression and neuronal activity influence one another. As described above,
A

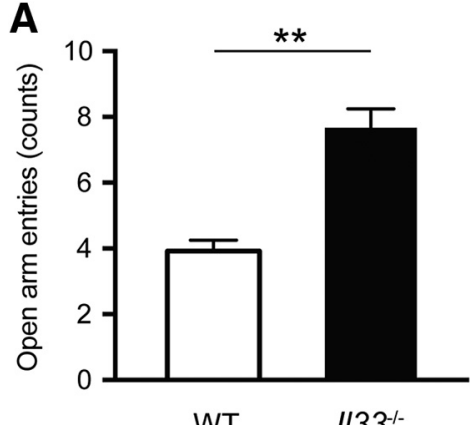

WT

C

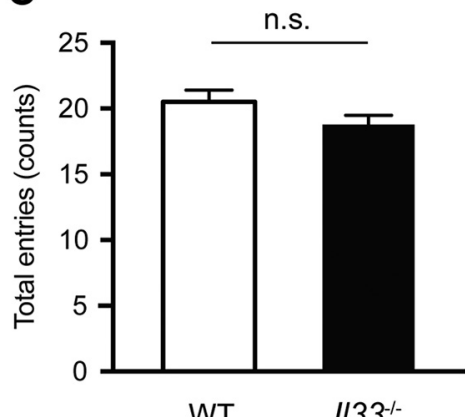

B

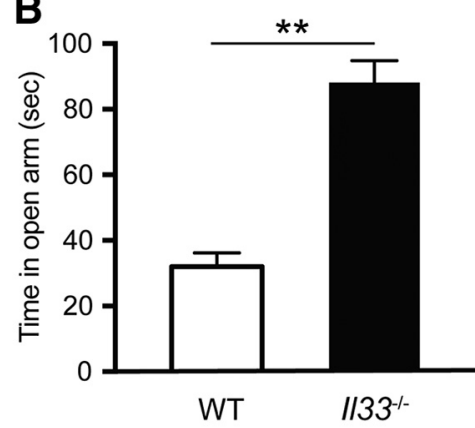

D

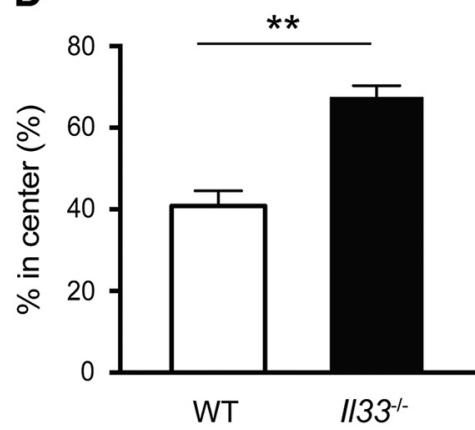

Figure 2. Reduced anxiety-like behavior in $/ / 33^{-1-}$ mice. $\boldsymbol{A}$, Increased open arm entries into the EPM. $\boldsymbol{B}$, Increased time spent in the open arms in the EPM. C, No difference in total entries between WT and $/ / 33^{-/-}$mice in the EPM. WT mice, $n=12 ; / / 33^{-/-}$mice, $n=9$. $\boldsymbol{D}$, Increased time spent in the center during the OFT. WT mice, $n=9$; $/ 133^{-/-}$mice, $n=7$. Each bar represents mean \pm SEM; n.s, not significant; $* * p<0.01$ (Student's $t$ test; see Table 2 for the detail of statistical analysis). 
A
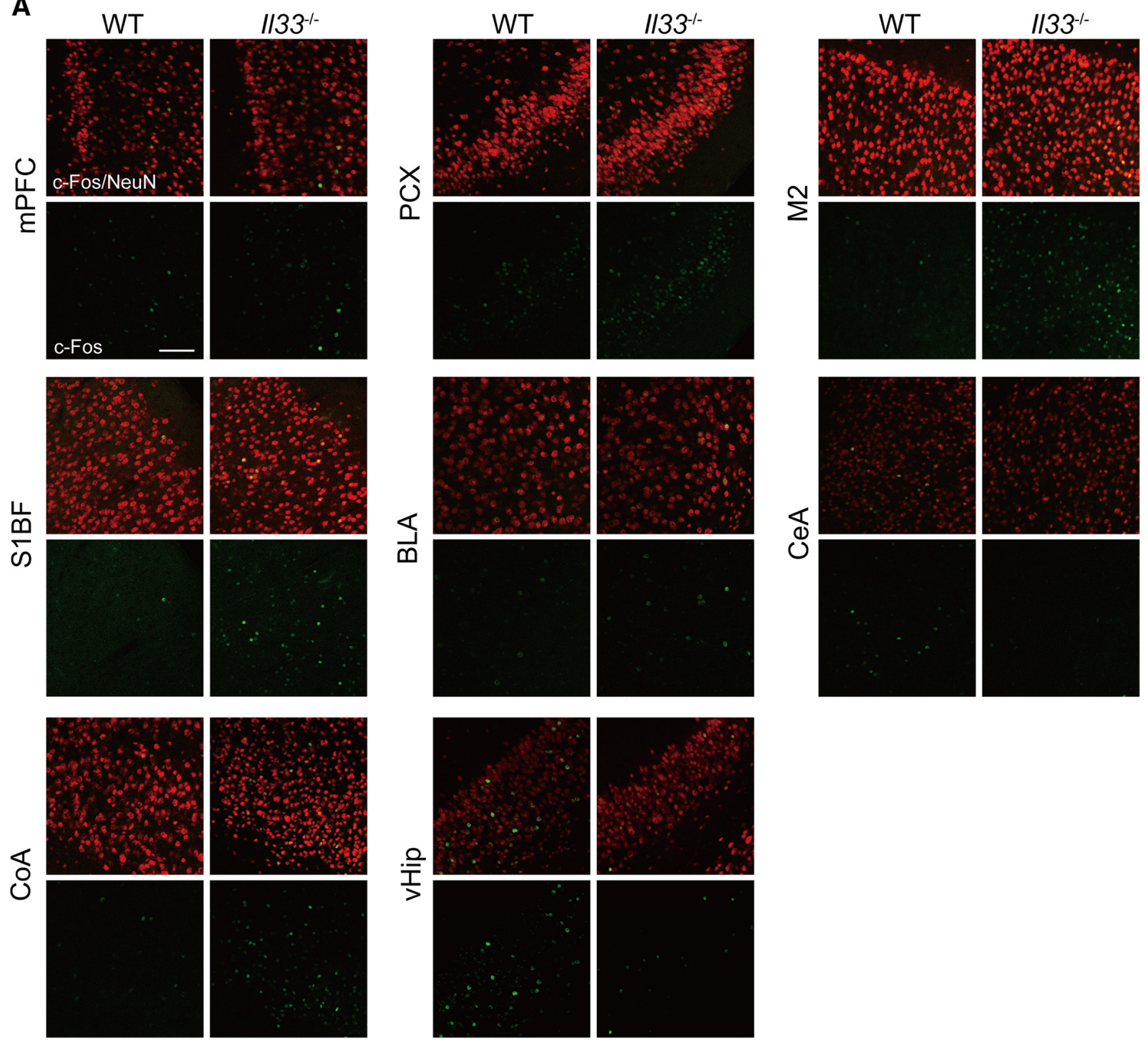

B

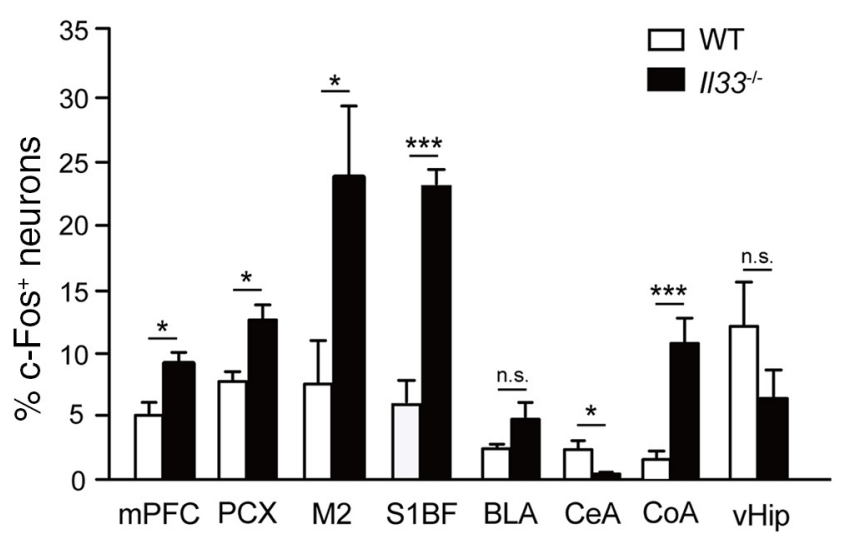

Figure 3. Altered c-Fos immunoreactivity in brain regions related to anxiety in $/ 133^{-1-}$ mice. $\boldsymbol{A}$, Representative images of $\mathrm{c}-\mathrm{Fos}$ expression in $\mathrm{NeuN}^{+}$neurons. Location of each brain region is indicated in Fig. $1 D$ [a, mPFC; $\boldsymbol{b}, \mathrm{M} 2 ; \boldsymbol{d}, \mathrm{PCX} ; \boldsymbol{e}, \mathrm{S} 1 \mathrm{BF} ; \boldsymbol{g}, \mathrm{CeA} ; \boldsymbol{h}, \mathrm{BLA} ;$ $\boldsymbol{i}$, CoA; $\boldsymbol{k}$, ventral hippocampus (vHip)]. B, Quantification of c-Fos expression in various brain regions. Percentages of c-Fos- 
continued

expressing neurons among all neurons ( $\mathrm{NeuN}^{+}$cells) were calculated and compared between WT and $/ / 33^{-/-}$mice $(n=3-4)$. Scale bar, $100 \mu \mathrm{m}$. Each bar represents mean \pm SEM; n.s., not significant; $* p<0.05, * * p<0.01$ (Student's $t$ test; see Table 2 for the detail of statistical analysis).

c-Fos immunoreactivity was significantly increased in the mPFC, PCX, M2, somatosensory cortex, barrel field (S1BF), and CoA regions of $1 / 33^{-1-}$ mice after the EPM (Fig. 3B). Thus, we analyzed the correlation between expression of IL-33 in these areas in WT mice and fold change of ${\mathrm{c}-F o s^{+}}$neurons in $1 / 33^{-1-}$ mice compared to WT mice. We did not observe a correlation between the number of $\mathrm{IL}_{-} 33^{+}$cells and the fold change of $\mathrm{c}-\mathrm{Fos}^{+}$ neurons in WT mice normalized with $/ / 33^{-1-}$ mice in these regions after the EPM (Fig. $4 A$ ). We also analyzed the correlation between $\% \mathrm{C}^{-} \mathrm{Fos}^{+}$of $\mathrm{NeuN}^{+}$neurons and IL-33 expression of WT mice after the EPM, but did not observe any correlation (Fig. $4 B$ ). We then examined the influence of the EPM experiment, a stressful paradigm that induces neuronal activities, on the levels of IL-33 expression. We did not observe any significant difference in the number of IL-33-expressing cells in several brain areas in mice with or without the EPM (Fig. 4C,D). qRTPCR analysis of $/ 133$ mRNA expression also confirmed these findings (Fig. 4E). Thus, our data suggest that $/ / 33$ deficiency widely affects neuronal activity throughout the brain, but that the levels of IL-33 expression and local neuronal activities are not directly related.

\section{Intact sociability and impaired social recognition in II3 $3^{-/-}$mice}

To address whether IL-33 deficiency specifically influences anxiety-related behaviors, we also assessed the social behaviors of $1 / 33^{-1-}$ mice in the three-chamber social interaction test (Moy et al., 2004; Gkogkas et al., 2013; Lipina et al., 2013; Filiano et al., 2016). In the sociability trial, where a test mouse spends time interacting with either an object or another mouse, $/ 133^{-1-}$ mice showed a clear preference to the mouse, the same behavior as WT mice (Fig. $5 A, B$ ). In contrast, in the social novelty preference trial, where a test mouse interacts with either a novel mouse or a familiar mouse, $/ / 33^{-/-}$mice did not show an increase in interaction with the novel mouse, as was observed in WT mice (Fig. $5 C, D$ ). These results suggest that IL-33 is also required for social novelty recognition. Social novelty recognition is known to be affected by olfactory impairment (Spehr et al., 2006), and IL-33 is expressed in the PCX, one of the main components of the olfactory system. Thus, IL-33 deficiency may impair social novelty recognition, via dysregulation of neuronal circuits and/or olfaction.

\section{Discussion}

In this study, we reported a novel role of the nuclear alarmin IL-33 in the regulation of anxiety-related and social behaviors in mice. We found that $/ / 33$ deficiency resulted in anxiolytic behaviors in two well-established behavioral paradigms, the OFT and the EPM. Consistent with these behavioral changes, we observed that the expression of an immediate early gene, c-Fos, was sig- nificantly altered in brain regions related to anxiety in $\| 33^{-1-}$ mice. $\| / 33^{-1-}$ mice also showed impaired social recognition in the three-chamber social interaction test. In addition, we found that IL-33 expression patterns considerably varied across different brain regions in adult mice and that subsets of Olig ${ }^{+}$oligodendrocyte-lineage cells and $\mathrm{S} 100 \beta^{+}$astrocytes did not express IL-33. Thus, IL-33 expression may represent glial subpopulations whose distribution varies between brain regions. Although IL-33 expression was detected in the adult brain, there was no correlation between IL-33 expression and c-Fos immunoreactivity changes. Thus, our study suggested that //33 deficiency may dysregulate the development and/or maturation of multiple neuronal circuits.

What neuronal circuitry is affected by $1 / 33$ deficiency? The neural circuitry underlying anxiety-related behaviors is believed to consist of stratified structures, from detection (e.g., thalamus, sensory cortex), to interpretation (e.g., amygdala, hippocampus, LS), evaluation (e.g., mPFC, NAc, hypothalamus, VTA), and response (e.g., motor cortex, brainstem; Silveira et al., 1993; Linden et al., 2003; Salomé et al., 2004; Sul et al., 2011; Tye et al., 2011; Huang et al., 2013; Likhtik et al., 2014; Calhoon and Tye, 2015). On the other hand, the brain areas underlying social recognition or social memory are reported as olfactory bulb, medial amygdala, entorhinal cortex, perirhinal cortex and hippocampus (Camats Perna and Engelmann, 2017). Thus, it is unlikely that the behavioral alterations of $1 / 33^{-1-}$ mice were explained by some common neuronal circuits where IL-33 signaling plays a critical modulatory role. Rather, it is speculated that I/33 deficiency dysregulates the development and/or maturation of multiple neuronal circuits relevant to anxiety and social behaviors. Our data that IL-33 expression is neither modified by behaviors nor correlated with c-Fos staining patterns in the adult brain support this hypothesis. Previous studies showed that IL-33 expression dynamically changed across various brain regions during the postnatal period (Wicher et al., 2013). Future studies are required to address the impact of //33 deficiency in different brain areas at different developmental stages on anxiety-related and social behaviors.

The mechanisms by which IL-33 influences the development and/or maturation of multiple neuronal circuits linked to anxiety and social recognition-related behaviors are not clear at this moment. Previous studies reported that alterations in oligodendrocytes and astrocytes impair these behaviors in mice. Studies on mice with mutations in oligodendrocyte-related genes, such as Cnp1 and Plp1, and a mouse model of cuprizone-induced demyelination suggest that the loss of integrity of small-diameter myelinated axons due to oligodendrocyte dysfunction may be a common mechanism underlying reduced anxiety-like behaviors (Ganter et al., 1999; Evangelou 
A

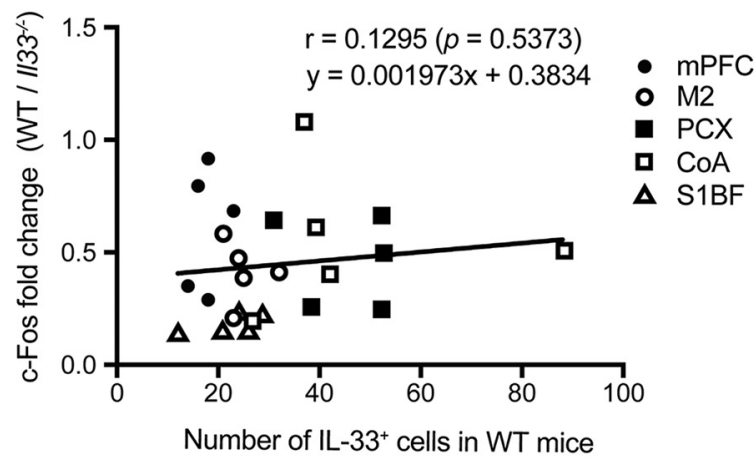

B
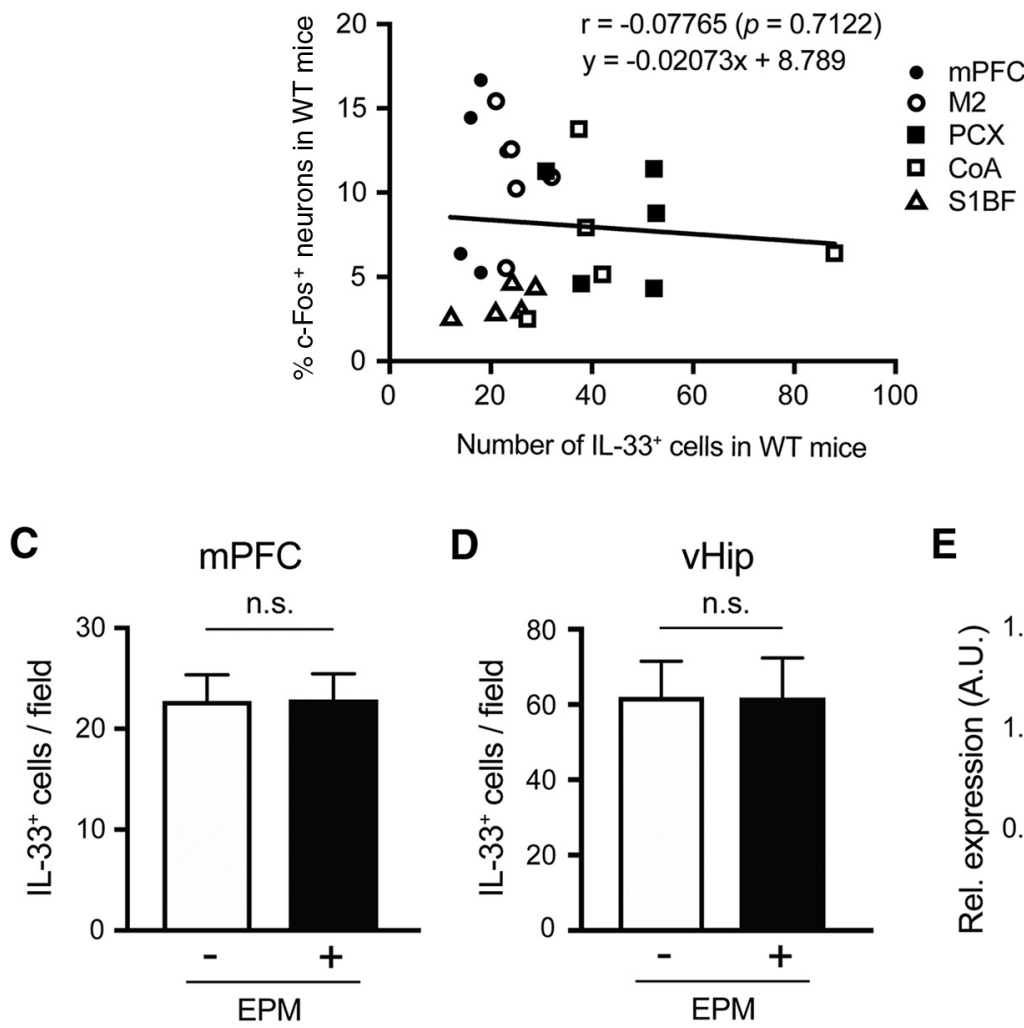

$\mathbf{E}$

॥33 mRNA

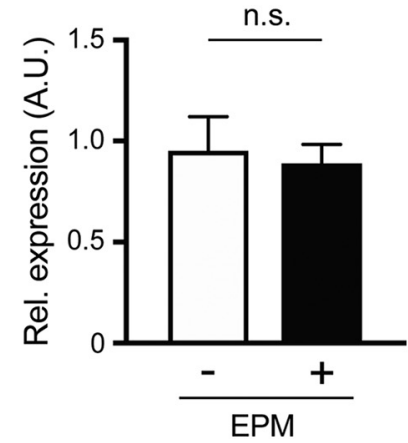

Figure 4. Relationship between IL-33 expression and c-Fos immunoreactivity. $\boldsymbol{A}$, Correlation between the number of IL-33 ${ }^{+}$cells per field in WT mice and fold change of \% c-Fos ${ }^{+}$neurons $\left(\mathrm{NeuN}^{+}\right.$cells) per field in WT mice normalized with average $\% \mathrm{c}^{-F o s}{ }^{+}$neurons per field in $/ / 33^{-1-}$ mice. Each dot refers to the brain region of an individual mouse (WT mice, $n=5 ; / / 33^{-1-}$ mice, $n=5$ ). $\boldsymbol{B}$, Correlation between the \% c-Fos ${ }^{+}$neurons per field in WT mice and the number of IL- $33^{+}$cells per field in WT mice based on c-Fos elevated brain regions in $I I 33^{-1-}$ mice after EPM. Each dot refers to the brain region of an individual mouse. $\boldsymbol{C}, \boldsymbol{D}$, No difference in IL-33 expression in the $\mathrm{mPFC}$ and ventral hippocampus (vHip) between WT mice with and without the EPM (EPM ${ }^{+}$and $\left.\mathrm{EPM}^{-}\right)$. $\boldsymbol{E}$, No difference in the //33 mRNA expression in the fontal cortex between $\mathrm{EPM}^{+}$and $\mathrm{EPM}^{-}$. $\mathrm{EPM}^{+} n=4, \mathrm{EPM}^{-} n=4$. A.U., arbitrary unit. Each bar represents mean $\pm \mathrm{SEM}$ n.s., not significant (Pearson correlation, Student's $t$ test; see Table 1 for the detail of statistical analysis).

et al., 2001; Lappe-Siefke et al., 2003; Edgar et al., 2004; 2009; 2011; Tanaka et al., 2009; Xu et al., 2009). In addition, mice deficient in CD38, which regulates astrocyte and oligodendrocyte maturation (Hattori et al., 2017), are reported to show impaired social recognition (Kim et al., 2016). Loss of astrocytes in the prefrontal cortex has been shown to induce anxiety-like behaviors in rats (Banasr and Duman, 2008). Thus, there are at least three potential mechanisms by which IL-33 affects anxiety and social novelty recognition. First, IL-33 in oligodendrocytes may be required for the maintenance of small-diameter axons and thus neuronal connections across different brain regions related to these behaviors. Second, IL-33 may be required for the development and maturation of astrocytes and/or the proper astrocytic modulation of neuronal activities. Third, IL-33 may play the abovementioned roles both in oligodendrocytes and astrocytes, which together contribute to anxiety and social novelty 


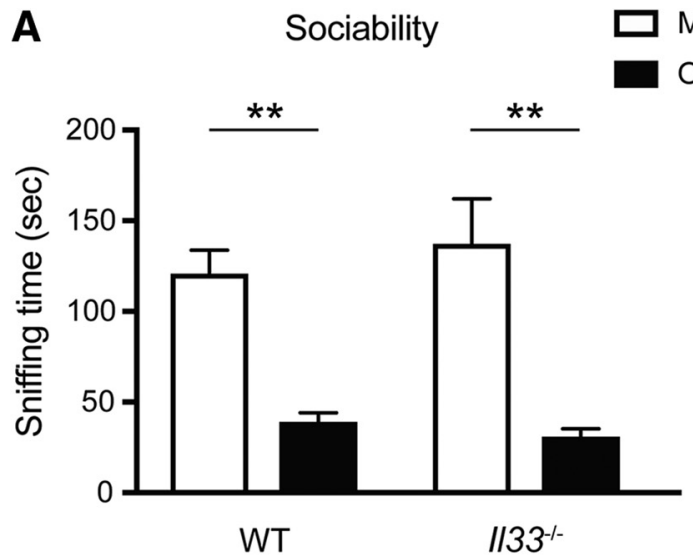

Mouse

B
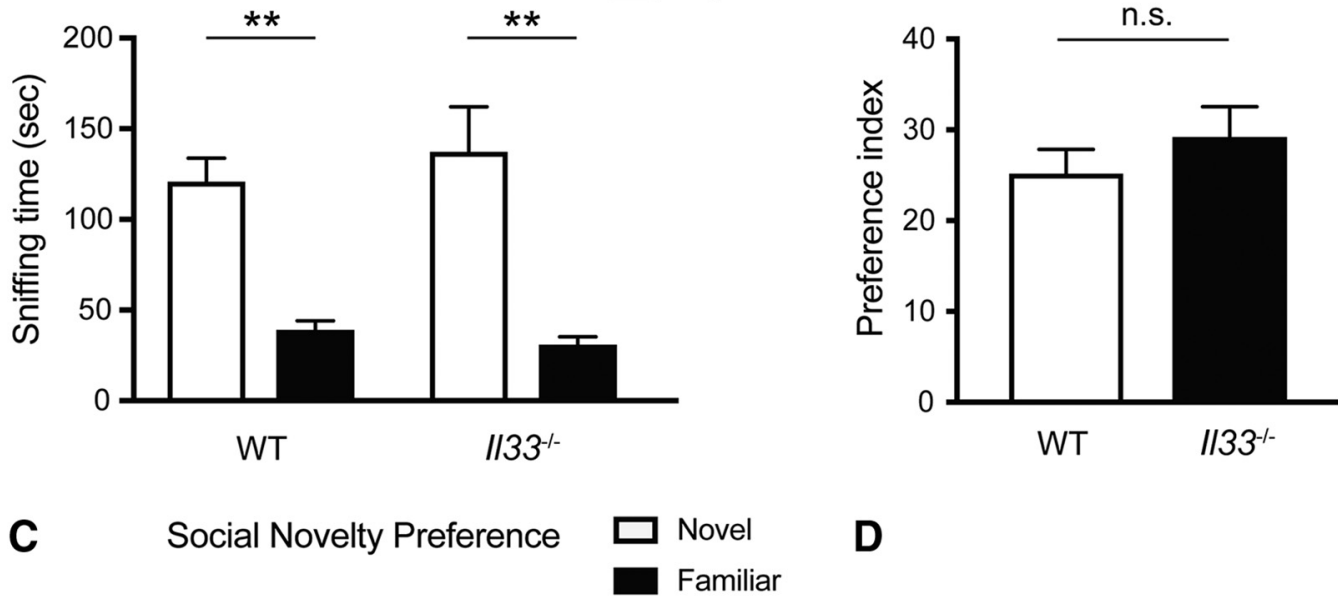

D
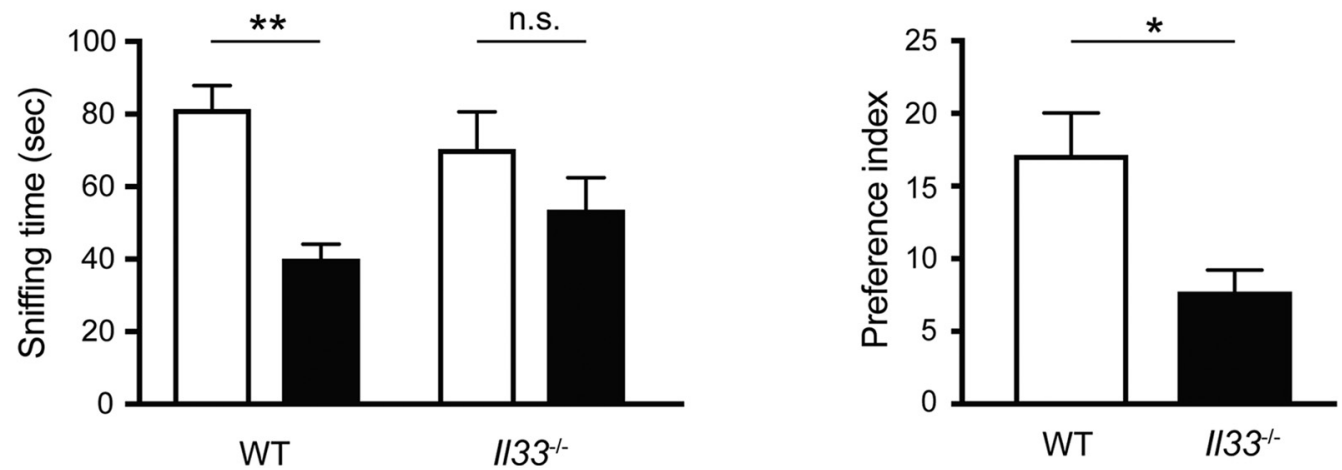

Figure 5. Altered social behaviors in $/ / 33^{-1-}$ mice. A, No significant difference in sociability between WT and $/ / 33^{-1-}$ mice. $\left(F_{\text {genotype } x \text { chamber(1,22) }}=0.9178, p=0.3485 ; F_{\text {genotype(1,22) }}=0.09669, p=0.7588 ; F_{\text {Chamber(1,22) }}=54.44, p<0.001\right)$. Both WT and $1 / 33^{-1-}$ mice preferred mice to objects $(* * p<0.01$, post hoc Sidak test). $\boldsymbol{B}$. Preference index data for sociability behaviors $(p=$ 0.3587 , Student's $t$ test). $\boldsymbol{C}$, Reduced preference to novel mice in $/ / 33^{-1-}$ mice. WT and $/ / 33^{-1-}$ mice differed significantly in preference trial $\left(F_{\text {genotype } x \text { chamber }(1,22)}=4.681, p<0.05 ; F_{\text {genotype }(1,22)}=0.00224, p=0.8824 ; F_{\text {Chamber }(1,22)}=26.34 ; p<0.0001\right)$. Only WT mice showed a significant preference to novel mice $(* * p<0.01$, post hoc Sidak test). $\boldsymbol{D}$, Preference index data for social novelty preference. $/ 133^{-1-}$ group showed a significantly lower preference index than the WT group (*p $<0.05$, Student's $t$ test). Each bar represents mean \pm SEM; n.s., not significant. See Table 2 for the detail of statistical analysis.

recognition. Finally, it needs to be determined whether IL-33 functions as a cytokine or a transcriptional modulator. If IL-33 functions as a cytokine, the effect is mediated via its receptor ST2. Because ST2 is expressed in microglia in the adult brain (Yasuoka et al., 2011; Yang et al., 2017), altered microglia-neuron interactions may also underlie neuronal dysfunction and behavioral abnormalities. If IL-33 functions as a transcriptional modulator, altered glial cell functions in $1 / 33^{-1-}$ mice can be explained by changes in gene expression patterns. Further studies are required to address these various possibilities to understand the mechanisms by which IL-33 influences brain development and/or maturation.

It is likely that various behaviors may be profoundly impaired in $/ 133^{-1-}$ mice, because IL-33 has been reportedly expressed in various brain regions and dynamically changed throughout brain development (Wicher et al., 2013). In particular, social novelty recognition is known to be affected by olfactory impairment (Spehr et al., 2006). Given that c-Fos immunoreactivity was altered in the brain regions related to sensory processing in $1 / 33^{-1-}$ mice, altered social novelty recognition in $/ / 33^{-/-}$mice may have been caused by general impairment of olfactory sensory processing. Alternatively, social novelty recognition deficits may indicate general impairment of recognition memory in $1 / 33^{-1-}$ mice. Further behavioral assessments, including olfaction and memory tests are required to address these issues in future studies. As discussed above, systematic experiments using cell-type-specific deletion of the I/33 gene in WT mice and/or recovery of IL-33 expression in $1 / 33^{-1-}$ mice during brain development and in adulthood are necessary to clarify the exact role of IL-33 in these behaviors.

IL-33 is also expressed outside of the brain. Although the level of IL-33 in the sera of WT mice was below the ELISA assay detection threshold, it is possible that a subthreshold level of IL-33 circulates in the blood and reaches the brain to influence its function and behavior. In addition, //33 deficiency in peripheral organs may affect the brain via another mediator (e.g., another cytokine, metabolites, neural connections). One recent study revealed that IL-33 regulates gut microbiota homeostasis by 
promoting IgA production from B cells (Malik et al., 2016). Because germ-free mice, which lack gut microbiota, have been shown to exhibit less anxiety-like behavior (Diaz Heijtz et al., 2011; Neufeld et al., 2011; Clarke et al., 2013), IL-33 deficiency may cause anxiolytic effects and impairments of social behaviors by altering the composition of gut microbiota. IL-33 has also been shown to maintain the immune function of meninges (Gadani et al., 2016), which can influence brain development by secreting trophic factors (Siegenthaler et al., 2009; Lehtinen and Walsh, 2011). Future studies on brain-specific deletion of the //33 gene will address the contribution of central and peripheral IL-33 to anxiety-related and social behaviors.

An increasing number of studies report that day/night cycle significantly affects behavioral phenotypes of rodents that are nocturnal (Roedel et al., 2006; Fonken et al., 2009; Sidor et al., 2015). Particularly, emotional and stress-related behaviors are known to be affected by day/night cycle (Fonken et al., 2009; Leach et al., 2013; Tapia-Osorio et al., 2013; Griesauer et al., 2014; BenHamo et al., 2016). While the findings under an inactive phase of rodents in a nonreversed day/night cycle provide new biological insights into their behaviors, the analysis of their behaviors under the active phase in a reversed day/ night cycle will be helpful to determine the biological significance of the findings. Future studies of $/ 133^{-/-}$mice under an active phase will be important to confirm the current findings and identify additional behavioral abnormalities.

\section{References}

Ali S, Mohs A, Thomas M, Klare J, Ross R, Schmitz ML, Martin MU (2011) The dual function cytokine IL-33 interacts with the transcription factor NF- $\kappa \mathrm{B}$ to dampen NF- $\kappa \mathrm{B}$-stimulated gene transcription. J Immunol 187:1609-1616. CrossRef Medline

Aston C, Jiang L, Sokolov BP (2005) Transcriptional profiling reveals evidence for signaling and oligodendroglial abnormalities in the temporal cortex from patients with major depressive disorder. Mol Psychiatry 10:309-322. CrossRef Medline

Banasr M, Duman RS (2008) Glial loss in the prefrontal cortex is sufficient to induce depressive-like behaviors. Biol Psychiatry 64: 863-870. CrossRef Medline

Ben-Hamo M, Larson TA, Duge LS, Sikkema C, Wilkinson CW, de la Iglesia HO, González MM (2016) Circadian forced desynchrony of the master clock leads to phenotypic manifestation of depression in rats. eNeuro 3.

Calhoon GG, Tye KM (2015) Resolving the neural circuits of anxiety. Nat Neurosci 18:1394-1404. CrossRef Medline

Camats Perna J, Engelmann M (2017) Recognizing others: rodent's social memories. Curr Top Behav Neurosci 30:25-45. CrossRef Medline

Chapuis J, Hot D, Hansmannel F, Kerdraon O, Ferreira S, Hubans C, Maurage CA, Huot L, Bensemain F, Laumet G, Ayral AM, Fievet N, Hauw JJ, DeKosky ST, Lemoine $Y$, Iwatsubo $T$, Wavrant-Devrièze F, Dartigues JF, Tzourio C, Buée L, et al. (2009) Transcriptomic and genetic studies identify IL-33 as a candidate gene for Alzheimer's disease. Mol Psychiatry 14:1004-1016. CrossRef Medline

Clarke G, Grenham S, Scully P, Fitzgerald P, Moloney RD, Shanahan F, Dinan TG, Cryan JF (2013) The microbiome-gut-brain axis during early life regulates the hippocampal serotonergic system in a sex-dependent manner. Mol Psychiatry 18:666-673. CrossRef

Diaz Heijtz R, Wang S, Anuar F, Qian Y, Björkholm B, Samuelsson A, Hibberd ML, Forssberg H, Pettersson S (2011) Normal gut microbiota modulates brain development and behavior. Proc Natl Acad Sci USA 108:3047-3052. CrossRef Medline
Dohi E, Tanaka S, Seki T, Miyagi T, Hide I, Takahashi T, Matsumoto M, Sakai N (2012) Hypoxic stress activates chaperone-mediated autophagy and modulates neuronal cell survival. Neurochem Int 60:431-442. CrossRef Medline

Dubal DB, Zhu L, Sanchez PE, Worden K, Broestl L, Johnson E, Ho K, Yu GQ, Kim D, Betourne A, Kuro OM, Masliah E, Abraham CR, Mucke $L$ (2015) Life extension factor klotho prevents mortality and enhances cognition in hAPP transgenic mice. J Neurosci 35:23582371. CrossRef

Duncan GE, Knapp DJ, Breese GR (1996) Neuroanatomical characterization of Fos induction in rat behavioral models of anxiety. Brain Res 713:79-91. Medline

Edgar JM, McLaughlin M, Yool D, Zhang SC, Fowler JH, Montague P, Barrie JA, McCulloch MC, Duncan ID, Garbern J, Nave KA, Griffiths IR (2004) Oligodendroglial modulation of fast axonal transport in a mouse model of hereditary spastic paraplegia. J Cell Biol 166:121-131. CrossRef

Edgar JM, McLaughlin M, Werner HB, McCulloch MC, Barrie JA, Brown A, Faichney AB, Snaidero N, Nave KA, Griffiths IR (2009) Early ultrastructural defects of axons and axon-glia junctions in mice lacking expression of Cnp1. Glia 57:1815-1824. CrossRef Medline

Edgar N, Sibille E (2012) A putative functional role for oligodendrocytes in mood regulation. Transl Psychiatry 2:e109. CrossRef Medline

Edgar NM, Touma C, Palme R, Sibille E (2011) Resilient emotionality and molecular compensation in mice lacking the oligodendrocytespecific gene Cnp1. Transl Psychiatry 1:e42. CrossRef

Ertürk A, Mentz S, Stout EE, Hedehus M, Dominguez SL, Neumaier L, Krammer F, Llovera G, Srinivasan K, Hansen DV, Liesz A, Scearce-Levie KA, Sheng M (2016) Interfering with the chronic immune response rescues chronic degeneration after traumatic brain injury. J Neurosci 36:9962-9975. CrossRef Medline

Evangelou N, Konz D, Esiri MM, Smith S, Palace J, Matthews PM (2001) Size-selective neuronal changes in the anterior optic pathways suggest a differential susceptibility to injury in multiple sclerosis. Brain 124:1813-1820. Medline

Filiano AJ, Xu Y, Tustison NJ, Marsh RL, Baker W, Smirnov I, Overall CC, Gadani SP, Turner SD, Weng Z, Peerzade SN, Chen H, Lee KS, Scott MM, Beenhakker MP, Litvak V, Kipnis J (2016) Unexpected role of interferon- $\gamma$ in regulating neuronal connectivity and social behaviour. Nature 535:425-429. CrossRef Medline

Fonken LK, Finy MS, Walton JC, Weil ZM, Workman JL, Ross J, Nelson RJ (2009) Influence of light at night on murine anxiety- and depressive-like responses. Behav Brain Res 205:349-354. CrossRef Medline

Fu AK, Hung KW, Yuen MY, Zhou X, Mak DS, Chan IC, Cheung TH, Zhang B, Fu WY, Liew FY, Ip NY (2016) IL-33 ameliorates Alzheimer's disease-like pathology and cognitive decline. Proc Natl Acad Sci USA 113:E2705-E2713. CrossRef Medline

Gadani SP, Walsh JT, Smirnov I, Zheng J, Kipnis J (2015) The glia-derived alarmin IL-33 orchestrates the immune response and promotes recovery following CNS injury. Neuron 85:703-709. CrossRef Medline

Gadani SP, Smirnov I, Smith AT, Overall CC, Kipnis J (2016) Characterization of meningeal type 2 innate lymphocytes and their response to CNS injury. J Exp Med 214:285-296.

Ganter P, Prince C, Esiri MM (1999) Spinal cord axonal loss in multiple sclerosis: a post-mortem study. Neuropathol Appl Neurobiol 25:459-467. Medline

Gkogkas CG, Khoutorsky A, Ran I, Rampakakis E, Nevarko T, Weatherill DB, Vasuta C, Yee S, Truitt M, Dallaire P, Major F, Lasko P, Ruggero D, Nader K, Lacaille JC, Sonenberg N (2013) Autismrelated deficits via dysregulated elF4E-dependent translational control. Nature 493:371-377. CrossRef Medline

Gompf HS, Mathai C, Fuller PM, Wood DA, Pedersen NP, Saper CB, Lu J (2010) Locus ceruleus and anterior cingulate cortex sustain wakefulness in a novel environment. J Neurosci 30:14543-14551. CrossRef 
Griesauer I, Diao W, Ronovsky M, Elbau I, Sartori S, Singewald N, Pollak DD (2014) Circadian abnormalities in a mouse model of high trait anxiety and depression. Ann Med 46:148-154. CrossRef

Hallgren KA (2012) Computing inter-rater reliability for observational data: an overview and tutorial. Tutor Quant Methods Psychol 8:23-34. Medline

Hamidi M, Drevets WC, Price JL (2004) Glial reduction in amygdala in major depressive disorder is due to oligodendrocytes. Biol Psychiatry 55:563-569. CrossRef Medline

Hattori T, Kaji M, Ishii H, Jureepon R, Takarada-lemata M, Minh Ta H, Manh Le T, Konno A, Hirai H, Shiraishi Y, Ozaki N, Yamamoto Y, Okamoto H, Yokoyama S, Higashida H, Kitao Y, Hori O (2017) CD38 positively regulates postnatal development of astrocytes cell-autonomously and oligodendrocytes non-cell-autonomously. Glia 65:974-989. CrossRef Medline

Huang AC, Shyu BC, Hsiao S, Chen TC, He AB (2013) Neural substrates of fear conditioning, extinction, and spontaneous recovery in passive avoidance learning: a c-fos study in rats. Behav Brain Res 237:23-31. CrossRef Medline

Jiang HR, Milovanović M, Allan D, Niedbala W, Besnard AG, Fukada SY, Alves-Filho JC, Togbe D, Goodyear CS, Linington C, Xu D, Lukic ML, Liew FY (2012) IL-33 attenuates EAE by suppressing $\mathrm{IL}-17$ and IFN- $\gamma$ production and inducing alternatively activated macrophages. Eur J Immunol 42:1804-1814. CrossRef Medline

Kim S, Kim T, Lee HR, Jang EH, Ryu HH, Kang M, Rah SY, Yoo J, Lee B, Kim JI, Lim CS, Kim SJ, Kim UH, Lee YS, Kaang BK (2016) Impaired learning and memory in CD38 null mutant mice. Mol Brain 9:16. CrossRef Medline

King BM, Minium EW (2003) Statistical reasoning in psychology and education, Ed 4. New York: Wiley.

Koo TK, Li MY (2016) A guideline of selecting and reporting intraclass correlation coefficients for reliability research. J Chiropr Med 15: 155-163. CrossRef Medline

Langford DJ, Bailey AL, Chanda ML, Clarke SE, Drummond TE, Echols S, Glick S, Ingrao J, Klassen-Ross T, Lacroix-Fralish ML, Matsumiya L, Sorge RE, Sotocinal SG, Tabaka JM, Wong D, van den Maagdenberg AM, Ferrari MD, Craig KD, Mogil JS (2010) Coding of facial expressions of pain in the laboratory mouse. Nat Methods 7:447-449. CrossRef

Lappe-Siefke C, Goebbels S, Gravel M, Nicksch E, Lee J, Braun PE, Griffiths IR, Nave KA (2003) Disruption of Cnp1 uncouples oligodendroglial functions in axonal support and myelination. Nat Genet 33:366-374. CrossRef Medline

Leach G, Adidharma W, Yan L (2013) Depression-like responses induced by daytime light deficiency in the diurnal grass rat (Arvicanthis niloticus). PLoS One 8:e57115. CrossRef Medline

Lehtinen MK, Walsh CA (2011) Neurogenesis at the braincerebrospinal fluid interface. Annu Rev Cell Dev Biol 27:653-679. CrossRef Medline

Liew FY, Girard JP, Turnquist HR (2016) Interleukin-33 in health and disease. Nat Rev Immunol 16:676-689. CrossRef Medline

Likhtik E, Stujenske JM, Topiwala MA, Harris AZ, Gordon JA (2014) Prefrontal entrainment of amygdala activity signals safety in learned fear and innate anxiety. Nat Neurosci 17:106-113. CrossRef Medline

Linden AM, Baez M, Bergeron M, Schoepp DD (2003) Increased c-Fos expression in the centromedial nucleus of the thalamus in metabotropic glutamate 8 receptor knockout mice following the elevated plus maze test. Neuroscience 121:167-178. Medline

Linden AM, Greene SJ, Bergeron M, Schoepp DD (2004) Anxiolytic activity of the MGLU2/3 receptor agonist LY354740 on the elevated plus maze is associated with the suppression of stressinduced c-Fos in the hippocampus and increases in c-Fos induction in several other stress-sensitive brain regions. Neuropsychopharmacology 29:502-513. CrossRef

Lipina TV, Fletcher PJ, Lee FH, Wong AH, Roder JC (2013) Disrupted-in-schizophrenia-1 Gln31Leu polymorphism results in social anhedonia associated with monoaminergic imbalance and reduction of CREB and $\beta$-arrestin-1,2 in the nucleus accumbens in a mouse model of depression. Neuropsychopharmacology 38: 423-436. CrossRef

Malik A, Sharma D, Zhu Q, Karki R, Guy CS, Vogel P, Kanneganti TD (2016) IL-33 regulates the IgA-microbiota axis to restrain IL-1 $\alpha$ dependent colitis and tumorigenesis. J Clin Invest 126:44694481. CrossRef Medline

Martin NT, Martin MU (2016) Interleukin 33 is a guardian of barriers and a local alarmin. Nat Immunol 17:122-131. CrossRef Medline

Molofsky AB, Savage AK, Locksley RM (2015) Interleukin-33 in tissue homeostasis, injury, and inflammation. Immunity 42:1005-1019. CrossRef Medline

Montalvo-Ortiz JL, Bordner KA, Carlyle BC, Gelernter J, Simen AA, Kaufman $J$ (2016) The role of genes involved in stress, neural plasticity, and brain circuitry in depressive phenotypes: convergent findings in a mouse model of neglect. Behav Brain Res 315:71-74. CrossRef

Moy SS, Nadler JJ, Perez A, Barbaro RP, Johns JM, Magnuson TR, Piven J, Crawley JN (2004) Sociability and preference for social novelty in five inbred strains: an approach to assess autistic-like behavior in mice. Genes Brain Behav 3:287-302. CrossRef Medline

Nagy C, Suderman M, Yang J, Szyf M, Mechawar N, Ernst C, Turecki G (2015) Astrocytic abnormalities and global DNA methylation patterns in depression and suicide. Mol Psychiatry 20:320-328. CrossRef Medline

Neufeld KM, Kang N, Bienenstock J, Foster JA (2011) Reduced anxiety-like behavior and central neurochemical change in germfree mice. Neurogastroenterol Motil 23:255-264, e119. CrossRef

Niwa M, Kamiya A, Murai R, Kubo K, Gruber AJ, Tomita K, Lu L, Tomisato S, Jaaro-Peled H, Seshadri S, Hiyama H, Huang B, Kohda K, Noda Y, O’Donnell P, Nakajima K, Sawa A, Nabeshima T (2010) Knockdown of DISC1 by in utero gene transfer disturbs postnatal dopaminergic maturation in the frontal cortex and leads to adult behavioral deficits. Neuron 65:480-489. CrossRef Medline

Roedel A, Storch C, Holsboer F, Ohl F (2006) Effects of light or dark phase testing on behavioural and cognitive performance in DBA mice. Lab Anim 40:371-381. CrossRef Medline

Roussel L, Erard M, Cayrol C, Girard JP (2008) Molecular mimicry between IL-33 and KSHV for attachment to chromatin through the H2A-H2B acidic pocket. EMBO Rep 9:1006-1012. CrossRef Medline

Salomé N, Salchner $\mathrm{P}$, Viltart $\mathrm{O}$, Sequeira $\mathrm{H}$, Wigger A, Landgraf $\mathrm{R}$, Singewald N (2004) Neurobiological correlates of high (HAB) versus low anxiety-related behavior ( $\mathrm{LAB}$ ): differential Fos expression in HAB and LAB rats. Biol Psychiatry 55:715-723. CrossRef Medline

Schindelin J, Arganda-Carreras I, Frise E, Kaynig V, Longair M, Pietzsch T, Preibisch S, Rueden C, Saalfeld S, Schmid B, Tinevez JY, White DJ, Hartenstein V, Eliceiri K, Tomancak P, Cardona A (2012) Fiji: an open-source platform for biological-image analysis. Nat Methods 9:676-682. CrossRef Medline

Schmitz J, Owyang A, Oldham E, Song Y, Murphy E, McClanahan TK, Zurawski G, Moshrefi M, Qin J, Li X, Gorman DM, Bazan JF, Kastelein RA (2005) IL-33, an interleukin-1-like cytokine that signals via the IL-1 receptor-related protein ST2 and induces T helper type 2-associated cytokines. Immunity 23:479-490. CrossRef

Schneider CA, Rasband WS, Eliceiri KW (2012) NIH Image to ImageJ: 25 years of image analysis. Nat Methods 9:671-675. Medline

Shrout PE, Fleiss JL (1979) Intraclass correlations: uses in assessing rater reliability. Psychol Bull 86:420-428. Medline

Sidor MM, Rilett K, Foster JA (2010) Validation of an automated system for measuring anxiety-related behaviours in the elevated plus maze. J Neurosci Methods 188:7-13. CrossRef

Sidor MM, Spencer SM, Dzirasa K, Parekh PK, Tye KM, Warden MR, Arey RN, Enwright JF 3rd, Jacobsen JP, Kumar S, Remillard EM, Caron MG, Deisseroth K, McClung CA (2015) Daytime spikes in dopaminergic activity drive rapid mood-cycling in mice. Mol Psychiatry 20:1406-1419. CrossRef

Siegenthaler JA, Ashique AM, Zarbalis K, Patterson KP, Hecht JH, Kane MA, Folias AE, Choe Y, May SR, Kume T, Napoli JL, Peter- 
son AS, Pleasure SJ (2009) Retinoic acid from the meninges regulates cortical neuron generation. Cell 139:597-609. CrossRef Medline

Silveira MC, Sandner G, Graeff FG (1993) Induction of Fos immunoreactivity in the brain by exposure to the elevated plus-maze. Behav Brain Res 56:115-118. Medline

Spandidos A, Wang X, Wang H, Seed B (2010) PrimerBank: a resource of human and mouse PCR primer pairs for gene expression detection and quantification. Nucleic Acids Res 38:D792D799. CrossRef Medline

Spehr M, Kelliher KR, Li XH, Boehm T, Leinders-Zufall T, Zufall F (2006) Essential role of the main olfactory system in social recognition of major histocompatibility complex peptide ligands. J Neurosci 26:1961-1970. CrossRef Medline

Sul JH, Jo S, Lee D, Jung MW (2011) Role of rodent secondary motor cortex in value-based action selection. Nat Neurosci 14:12021208. CrossRef Medline

Tanaka H, Ma J, Tanaka KF, Takao K, Komada M, Tanda K, Suzuki A, Ishibashi T, Baba H, Isa T, Shigemoto R, Ono K, Miyakawa T, Ikenaka K (2009) Mice with altered myelin proteolipid protein gene expression display cognitive deficits accompanied by abnormal neuron-glia interactions and decreased conduction velocities. $J$ Neurosci 29:8363-8371. CrossRef Medline

Tapia-Osorio A, Salgado-Delgado R, Angeles-Castellanos M, Escobar C (2013) Disruption of circadian rhythms due to chronic constant light leads to depressive and anxiety-like behaviors in the rat. Behav Brain Res 252:1-9. CrossRef Medline

Tye KM, Prakash R, Kim SY, Fenno LE, Grosenick L, Zarabi H, Thompson KR, Gradinaru V, Ramakrishnan C, Deisseroth K (2011) Amygdala circuitry mediating reversible and bidirectional control of anxiety. Nature 471:358-362. CrossRef Medline

Uranova NA, Vostrikov VM, Orlovskaya DD, Rachmanova VI (2004) Oligodendroglial density in the prefrontal cortex in schizophrenia and mood disorders: a study from the Stanley Neuropathology Consortium. Schizophr Res 67:269-275. CrossRef Medline
Walf AA, Frye CA (2007) The use of the elevated plus maze as an assay of anxiety-related behavior in rodents. Nat Protoc 2:322328. CrossRef Medline

Wicher G, Husic E, Nilsson G, Forsberg-Nilsson K (2013) Developmental expression of IL-33 in the mouse brain. Neurosci Lett 555:171-176. CrossRef Medline

Xiong Y, Neifert S, Karuppagounder SS, Stankowski JN, Lee BD, Grima JC, Chen G, Ko HS, Lee Y, Swing D, Tessarollo L, Dawson TM, Dawson VL (2017) Overexpression of Parkinson's diseaseassociated mutation LRRK2 G2019S in mouse forebrain induces behavioral deficits and $\alpha$-synuclein pathology. eNeuro 4. CrossRef

Xiong Z, Thangavel R, Kempuraj D, Yang E, Zaheer S, Zaheer A (2014) Alzheimer's disease: evidence for the expression of interleukin-33 and its receptor ST2 in the brain. J Alzheimers Dis 40:297-308. CrossRef Medline

Xu H, Yang HJ, Zhang Y, Clough R, Browning R, Li XM (2009) Behavioral and neurobiological changes in C57BL/6 mice exposed to cuprizone. Behav Neurosci 123:418-429. CrossRef Medline

Yang Y, Liu H, Zhang H, Ye Q, Wang J, Yang B, Mao L, Zhu W, Leak RK, Xiao B, Lu B, Chen J, Hu X (2017) ST2/IL-33-dependent microglial response limits acute ischemic brain injury. $J$ Neurosci 37:4692-4704. CrossRef Medline

Yasuoka S, Kawanokuchi J, Parajuli B, Jin S, Doi Y, Noda M, Sonobe Y, Takeuchi H, Mizuno T, Suzumura A (2011) Production and functions of IL-33 in the central nervous system. Brain Res 1385: 8-17. CrossRef Medline

Yu JT, Song JH, Wang ND, Wu ZC, Zhang Q, Zhang N, Zhang W, Xuan SY, Tan L (2012) Implication of IL-33 gene polymorphism in Chinese patients with Alzheimer's disease. Neurobiol Aging 33: 1014.e11-14. CrossRef

Zhang J, Wang Y, Chi Z, Keuss MJ, Pai YM, Kang HC, Shin JH, Bugayenko A, Wang $H$, Xiong $Y$, Pletnikov MV, Mattson MP, Dawson TM, Dawson VL (2011) The AAA+ ATPase thorase regulates AMPA receptor-dependent synaptic plasticity and behavior. Cell 145:284-299. CrossRef Medline 